2. Baerlocher K, Gitzelmann R, Nussli R, Dumermuth G 1971 Infantile lactic acidosis due to hereditary fructose 1,6-diphosphatase deficiency. Helv Paediatr Acta 26:489

3. Coude FX, Saudubray JM, DeMaugre F, Marsac C, Leroux JP 1978 Dichloroacetate as treatment for congenital lactic acidosis. N Engl J Med 299:1365

4. Crooks $\mathrm{J} 1982$ Haemolytic jaundice in a neonate after intra-amniotic injection of methylene blue. Arch Dis Child 57:872

5. DeVivo DC, Hammond MW, Obert KA, Nelson JS, Pagliara AS 1979 Defective activation of the pyruvate dehydrogenase complex in subacute necrotizing encephalomyelopathy (Leigh's disease). Ann Neurol 6:483

6. DiMauro S, Mendell JR, Sahenk Z, Bashman D, Scarpa A, Scofield RM, Reiner C 1980 Fatal infantile mitochondrial myopathy and renal dysfunction due to cytochrome-C-oxidase deficiency. Neurology 30:795

7. Erickson RJ 1965 Familial infantile lactic acidosis. J Pediatr 66:1004

8. Falk RE, Cederbaum SD, Blau JP, Gibson GE, Mark RAP, Carrel RE 1976 Ketotic diet in management of pyruvate dehydrogenase deficiency. Pediatrics 58:713

9. Feldman GL, Wolf B 1979 Measurement of pyruvate carboxylase activity in amniotic fluid cells. Pediatr Res 14:153

10. Goodman LS, Gilman A 1975 The Pharmacological Basis of Therapeutics, fifth ed. 1979 MacMillan Co, Chicago, pp 1003-1004

11. Hansen TL, Christensen E 1979 Studies on pyruvate carboxylase from human fibroblasts and amniotic fluid cells. J Inher Metab Dis 2:23

12. Hartmann AF Sr, Wohlmann HJ, Purkerson ML, Wesley ME 1962 Lactate metabolism, studies of a child with a serious congenital deviation. J Pediatr 61:165

13. Haworth JC, Perry TL, Hansen S 1974 Lactic acidosis due to a defect in pyruvate metabolism in 3 siblings. Pediatr Res $8: 433$

14. Hommes FA, Bendien K, Elema JD, Bremer HJ, Lombeck I 1976 Two cases of phosphoenolpyruvate carboxykinase deficiency. Acta Paediatr Scand $65: 233$

15. Howell RR, Williams JC 1983 The glycogen storage diseases. In: Stanbury JB, Wyngaarden JB, Fredrickson DS, Goldstein, JL, Brown MS (eds) The Metabolic Basis of Inherited Disease. McGraw-Hill, New York, pp 141-166

16. Howell RR, Ashton, DM, Wyngaarden JB 1962 Glucose-6-phosphatase deficiency glycogen storage disease. Pediatrics 29: 553
17. Israels S, Haworth JC, Dunn HG, Applegarth DA 1976 Lactic acidosis in childhood. Adv Pediatr 22:267

18. Lancaster G, Mamer OA, Scriver CR, Lamm P, Tjoa S 1974 Branched-chain$\alpha$-keto acids, isolated as oxime derivatives; relationship to the corresponding hydroxy acids and amino acids in maple syrup urine disease. Metabolism 23.257

19. Oliva PB 1970 Lactic acidosis. Am J Med 48:209

20. Raghunathan R, Russell JD, Arirec IJ 1977 Pyruvate carboxylase and phosphoenolpyruvate carboxylase in cultured human fibroblasts. J Cell Physiol 92:285

21. Robinson BH, Taylor J, Sherwood WG 1980 The genetic heterogeneity of lactic acidosis: occurrence of recognizable inborn errors of metabolism in a pediatric population of lactic acidosis. Pediatr Res 14:956

22. Roth KS, Yang W, Allan L, Saunders M, Gravel R, Dakshinamurti K 1982 Prenatal administration of biotin in biotin responsive multiple carboxylase deficiency. Pediatr Res 16:126

23. Scriver CR, Mohyuddin F 1968 Amino acid transport in kidney: heterogeneity in AIB uptake. J Biol Chem 243:3207

24. Stromme JH, Borud O, Moe PJ 1976 Fatal lactic acidosis in a newborn attributable to a congeni.al defect of pyruvate dehydrogenase. Pediatr Res $10: 60$

25. Sweetman L 1981 Two forms of biotin-responsive multiple carboxylase deficiency. J Inher Metab Dis 4:53

26. Van Biervliet JPGM, Bruinis L, Ketting D, DeBree PK, Van DerHeiden C, Wadman SK, Bookelman H, Van Haelst U, Monnens LAH 1977 Mitochondrial myopathy with lactic acidemia, a DeToni-Fanconi-Debré syndrome, and a defective respiratory chain in voluntary striated muscles. Pediatr Res 11:1088

27. Vidailhet M, Lefebvre E, Beley G, Marsac C 1981 Neonatal lactic acidosis associated with pyruvate carboxylase deficiency. J Inher Metab Dis 4:131

28. Wick H, Scheizer K, Baumgartner R 1978 Thiamine dependency in a patient with congenital lactic acidemia due to pyruvate dehydrogenase deficiency. Agents Actions 7:405

29. Willems JL, Monnens LAH, Trybels JMF, Veerkamp JH, Meyer AEF, Van Dam K, Van Haelot U 1977 Leigh's encephalopathy in a patient with cytochrome oxidase deficiency in muscle tissue. Pediatrics 60:850

\title{
Oxidative Metabolism of Cord Blood Neutrophils: Relationship to Content and Degranulation of Cytoplasmic Granules
}

\author{
DANIEL R. AMBRUSO, BARBARA BENTWOOD, PETER M. HENSON, AND \\ RICHARD B. JOHNSTON, JR.
}

\begin{abstract}
Department of Pediatrics, The University of Colorado School of Medicine, National Jewish Hospital and Research Center/National Asthma Center, and the Belle Bonfils Memorial Blood Center,
\end{abstract} Denver, Colorado 80262

\begin{abstract}
Generation of oxygen metabolites is an important component of the neutrophil's armamentarium against microbes. Production of superoxide anion $\left(\mathrm{O}_{2}^{-}\right)$and generation of hydroxyl radical $(\mathrm{OH})$ were measured in neutrophils from cord blood of 12 vaginally delivered, term newborn infants and 12 adults after stimulation with phorbol myristate acetate (PMA) and opsonized zymosan. With either stimulus, generation of $\mathrm{OH}$ was relatively less than
\end{abstract}

Received March 1, 1983; accepted April 19, 1984.

Address reprints to Daniel R. Ambruso, M.D., Department of Pediatrics, University of Colorado Health Sciences Center (C-220), Denver, Colorado 80262.

These studies were supported by the Stacy True Memorial Fund and United States Public Health Service Grants AI 19423, AI 14148, AI 15853, and GM 24834 production of $\mathrm{O}_{2}^{-}$for all infants studied. This discrepancy might be related to abnormal release or diminished cell content of a cofactor necessary for production of $\mathrm{OH}$ from $\mathrm{O}_{2}^{-}$. Since both lactoferrin (LF) found in specific granules and myeloperoxidase (MPO) found in azurophilic granules have been shown to enhance $\mathrm{OH}$ generation, we compared degranulation of both granule types in response to PMA and opsonized zymosan and total neutrophil content of MPO, LF, and lysozyme in cord blood and adult neutrophils. Degranulation, even after pretreatment with cytochalasin $B$, was the same for newborn and adult neutrophils. Content of MPO was identical (adult, $204 \pm 24 A$ units, mean \pm SEM, $n=9$; newborn, $201 \pm 21, n=9$ ) but lysozyme was mildly diminished (adults, $111 \pm 10 \mathrm{~A}$ units; 
newborn, $89 \pm 6, n=9, p<0.05$ ), and lactoferrin was moderately decreased (adult, 89.0 $\pm 7.3 \mu \mathrm{g} / \mathrm{mg}$ cell protein, $n=11$; newborn, 43.2 $\pm 7.0, n=11, p<0.005$ ). Generation of $\mathrm{OH}$ in response to PMA and LF content were measured in seven cord blood-adult control pairs. Both LF and $\mathbf{O H}$ generation were diminished in newborn cells and there was a direct relationship between $\mathrm{OH}$ generation and $\mathrm{LF}$ content. Electron microscopic studies of newborn neutrophils demonstrated evidence of degranulation and loss of specific granules. These deficits may be related to defective bactericidal activity exhibited by neutrophils from neonates. Activation of neutrophils during parturition may be the cause of the decrease in specific granules and the diminished LF content. (Pediatr Res 18:1148-1153, 1984)

\section{Abbreviations}

PMA, phorbol myristate acetate

MPO, myeloperoxidase

PBS, phosphate-buffered saline

LF, lactoferrin

In spite of modern antibiotic therapy, morbidity and mortality associated with bacterial infections remain high during the newborn period. Specific abnormalities in several components of the immune system in newborns have been identified, including diminished adherence, chemotaxis, and microbicidal activity of neutrophils $(1,23,24)$. Oxygen metabolism is an important component of neutrophil microbicidal activity (6). Previous studies have demonstrated abnormalities in activation of the hexose monophosphate shunt, reduction of nitroblue tetrazolium dye and chemiluminescence of neutrophils from newborn infants $(24,26,39,41)$; and we have previously reported preliminary data suggesting that although neutrophils have the capacity to activate the respiratory burst, subsequent production of hydroxyl radical ( $\mathrm{OH}$ ), a particularly potent oxygen metabolite, is defective (3). In the present study, we explored more carefully the defect in generation of toxic oxygen metabolites by newborn neutrophils and its relationship to degranulation and content of granule proteins.

\section{MATERIALS AND METHODS}

Reagents. The following reagents were purchased commercially: superoxide dismutase, cytochrome $c$, thiourea, $\alpha$-keto- $\gamma$ methiolbutyric acid, Coomassie blue, Micrococcus lysodeiketicus, o-dianisidine, and Triton X-100 (Sigma Chemical Co., St. Louis, MO); zymosan (ICN Pharmaceuticals, Inc., Cleveland, $\mathrm{OH}$ ); (Consolidated Midland Corp., Brewster, NY); immunoglobulin fraction of rabbit antihuman lactoferrin and fluoresceinconjugated goat antirabbit immunoglobulin (Calbiochem-Behring, La Jolla, CA); IgG fraction of rabbit antihuman lactoferrin (U.S. Biochemical Corp., Cleveland, OH); and agarose (Seaplaque, FMC Corp., Marine Colloids Division, Rockland, ME).

Isolation of Neutrophils. Cord blood was obtained from the placenta immediately after delivery and anticoagulated with 510 units/ml heparin. For control studies, a blood sample similarly anticoagulated was drawn from a normal adult within a few minutes of procuring cord blood and run in parallel with the newborn sample. The gestational age of the newborns was 37 to $41 \mathrm{wk}$, and all were products of uncomplicated pregnancies, normal labors, and vaginal deliveries. No postnatal complications occurred and all Apgar scores at 1 and 5 min were $\leq 8$. General anesthesia or intravenous analgesia were not used in any of the deliveries.

Separation of neutrophils from whole blood was achieved with dextran sedimentation, centrifugation through Ficoll-Hypaque, and hypotonic lysis, as previously described (4). Cells from adult and cord blood isolated by this technique were $95-99 \%$ neutrophils, and $>98 \%$ were viable as determined by trypan blue exclusion. Differential counts were performed on Wright's stained smears of cord blood and adult samples. There were no gross morphologic differences between cord blood and adult neutrophils. Although cord blood samples tended to have more immature cells on smear (adult band forms: mean, 3\%, range, 0-8\%; metamyelocytes, $0 \%$ : cord blood band forms: mean, $4 \%$, range, $0-11 \%$; metamyelocytes, mean, $0.3 \%$, range, $0-2 \%$ ), these results could not account for the differences seen in subsequent assays.

Assays of oxygen metabolite generation. Production of superoxide anion $\left(\mathrm{O}_{2}^{-}\right)$was measured in resting and activated cells as superoxide dismutase-inhibitable reduction of cytochrome $c$, as previously described (16). Generation of hydroxyl radical ( $\mathrm{OH}$ ) in resting and stimulated neutrophils was measured by its interaction with $\alpha$-keto- $\gamma$-methiolbutyric acid to form ethylene, which was quantitated by gas chromatography $(8,9)$. Stimuli for optimal $\mathrm{O}_{2}^{-}$and ${ }^{\circ} \mathrm{OH}$ generation as previously described $(4,16)$ were opsonized zymosan $\left(1 \mathrm{mg} / 2.5 \times 10^{6}\right.$ cells $)$ and PMA $(50 \mathrm{ng} / \mathrm{ml})$.

Assay of degranulation. Exocytosis of MPO and lysozyme was quantitated by standard techniques (7). Opsonized zymosan $(0.4$ or $1 \mathrm{mg} / \mathrm{ml})$, PMA $(50 \mathrm{ng} / \mathrm{ml})$, or buffer was added to $4 \times 10^{6}$ neutrophils in Krebs-Ringer phosphate buffer with $0.2 \%$ dextrose (KRP-D buffer) and $0.25 \%$ bovine serum albumin in a total volume of $1 \mathrm{ml}$. After incubation at $37^{\circ} \mathrm{C}$ for $60 \mathrm{~min}$, the reaction tubes were centrifuged at $100 \times g$, and the supernatant was removed and assayed for MPO by oxidation of $o$-dianisidine (7) and lysozyme by lysis of $M$. lysodeiketicus (7). Total content of these enzymes was measured in unincubated cells resuspended in buffer with $0.1 \%$ Triton $\mathrm{X}-100$ and was expressed as $A$ units $\left(\Delta A / 4 \times 10^{6}\right.$ cells $\left./ \mathrm{min} \times 10^{3}\right)$. Assays were performed in duplicate for each stimulus, and the amount of protein released after stimulation was calculated as percentage of total cell content. In some experiments, the neutrophils were pretreated with cytochalasin $\mathrm{B}, 5 \mathrm{ng} / \mathrm{ml}$, for $5 \mathrm{~min}$ at $37^{\circ} \mathrm{C}$ before the stimuli were added.

Measurement of lactoferrin. LF content of the neutrophil fractions was determined by a modification of the rocket electrophoresis method of Laurell (21). Rabbit antihuman lactoferrin $(60 \mu \mathrm{l})$ was mixed with $10 \mathrm{ml}$ of $1 \%$ agarose, and $5 \mathrm{ml}$ of the mixture was transferred to a $75 \times 50 \mathrm{~mm}$ glass slide. Eight to 10 wells were cut into each slide. Samples or LF standards $(5 \mu \mathrm{l})$ were added to the wells, and the slides were placed in an electrophoresis chamber with barbital buffer, pH 8.6. Current (15 mA/ slide) was applied to the chamber for $4 \mathrm{~h}$ to produce migration

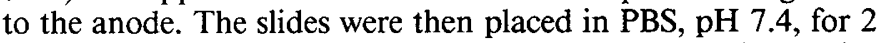
$\mathrm{h}$, rinsed once with distilled water, dried, and stained with Coomassie blue. The area under the rockets was determined by multiplying the height by the width of the rocket at half the height (42). The concentrations were determined by comparisons with standards of human milk LF run on each slide. Total protein content of neutrophils was measured by the technique of Lowry et al. (22), and LF levels were expressed as $\mu \mathrm{g}$ lactoferrin $/ \mathrm{mg}$ total cell protein.

LF content of intact cells was also evaluated using a fluorescent technique. Smears of peripheral blood were fixed in absolute methanol at $-20^{\circ} \mathrm{C}$ for $20 \mathrm{~min}$. The slides were then placed in PBS with $0.1 \%$ sodium azide and stored at $4^{\circ} \mathrm{C}$ until stained. Just before staining, all but a $1 \times 2 \mathrm{~cm}$ area of the peripheral blood smear was removed from the slide with a cotton swab. To this area, $25 \mu \mathrm{l}$ of the IgG fraction of rabbit antihuman lactoferrin was added, and the slides were incubated at room temperature for $20 \mathrm{~min}$. After washing the smears with two changes of PBS, $25 \mu \mathrm{l}$ of fluorescein-conjugated goat antirabbit immunoglobulin was added and allowed to incubate for $20 \mathrm{~min}$. Excess goat immunoglobulin was washed away with PBS and the smears were observed under an immunofluorescence microscope. Fifty to 100 neutrophils were observed on each smear.

Electron microscopy. Fifteen to $30 \mathrm{ml}$ of heparinized blood 
was collected from normal volunteers or placentas as noted above and leukocytes were separated by dextran sedimentation. After centrifugation, the leukocyte pellet was washed once with KRP$\mathrm{D}$ buffer, resuspended to a $1-\mathrm{ml}$ volume, and then mixed with an equal volume of $3 \%$ glutaraldehyde in $0.2 \mathrm{M}$ cacodylate buffer, $\mathrm{pH}$ 7.3. After a second centrifugation at $900 \times g$, the leukocytes were resuspended in $1.5 \%$ glutaraldehyde in $0.1 \mathrm{M}$

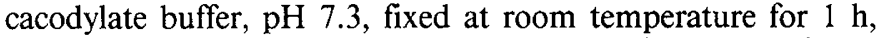
and stored at $4^{\circ} \mathrm{C}$ overnight before processing. Following a cacodylate buffer wash, the cells were postfixed with $1 \%$ osmium tetroxide in $0.1 \mathrm{M}$ cacodylate buffer, $\mathrm{pH} 7.3$ for $30 \mathrm{~min}$, centrifuged, and rinsed with $30 \%$ alcohol. After another centrifugation, the leukocytes were treated en bloc with $3.0 \%$ aqueous uranyl acetate for $15 \mathrm{~min}$ and washed with distilled water. The cells were then mixed in agarose, rapidly dehydrated in graded alcohols, cleared in propylene oxide, and infiltrated and embedded with Embed 812/Analdite 502 epoxy resin. Blocks were cured at $60^{\circ} \mathrm{C}$ for $16 \mathrm{~h}$ and repolymerized at $95^{\circ} \mathrm{C}$ for $3 \mathrm{~h}$. Thick and thin sections were cut with an LKB Nova microtome, and grids were examined with a Phillips 400T electron microscope at an accelerating voltage of $60 \mathrm{kV}$.

For each sample obtained from a newborn or adult control, 11 sections, each from a different neutrophil, were examined at a magnification of 12,000 . For each section, granules were identified as either azurophilic or specific based on density. Because of loss of some or all of the material contained within them, some granules appeared as partially or completely empty sacs. These could not be counted in one of the two granule classes and were noted as undetermined. For each section, the number of granules of each type (azurophilic, specific, or undetermined) were counted (total granules classified per section, 85 to 300 ) and expressed as percentage of total granules; and means for each sample were calculated from results of 11 sections.

\section{RESULTS}

The extent of release of $\mathrm{O}_{2}^{-}$and $\mathrm{OH}$ by neutrophils from cord blood of 12 vaginally delivered, term newborn infants, in comparison to release by neutrophils from paired adult controls, is summarized in Figure 1. Although production of $\mathrm{O}_{2}^{-}$by newborn neutrophils after stimulation with PMA was similar to that of adult cells (mean $=107 \%$ ), generation of $\mathrm{OH}$ was decreased (mean $=53 \%)$, and this difference was highly significant $(p<$ 0.005 , paired $t$ test). A similar discrepancy was seen when opsonized zymosan was used as a stimulus. Generation of $\mathrm{O}_{2}^{-}$with this stimulus was increased ( $127 \%$ of adult control), but the $\mathrm{OH}$ production was decreased $(90 \%), p<0.005$. Thus, for all infants studied, with either stimulus, generation of $\mathrm{OH}$ was relatively less than $\mathrm{O}_{2}^{-}$production.

These results might be explained by a deficiency of a cofactor necessary for the production of $\mathrm{OH}$ by neutrophils. Two granule proteins have been shown to enhance $\mathrm{OH}$ production, $\mathrm{LF}$ found in specific granules (4), and MPO found in the azurophilic granules (19). The inefficient production of $\mathrm{OH}$ by newborn neutrophils might be explained by an abnormal release of granule proteins into the phagocytic vacuole after plasma membrane stimulation, a decreased number of azurophilic or specific granules, or decreased content of myeloperoxidase or lactoferrin in the granules.

To explore these possibilities, we compared exocytsis of granule-associated proteins and total content of these proteins in neutrophils from newborns and normal adults. Exocytosis of MPO and lysozyme after stimulation of the cells with PMA or two different concentrations of opsonized zymosan is summarized in Figure 2. Results are shown in the absence and presence of cytochalasin B, which disorganizes microfilaments and permits maximal degranulation (14). With PMA or zymosan alone, newborn neutrophils released similar amounts of MPO and lysozyme to those of adult neutrophils. After pretreatment with cytochalasin B and stimulation with PMA or zymosan, newborn

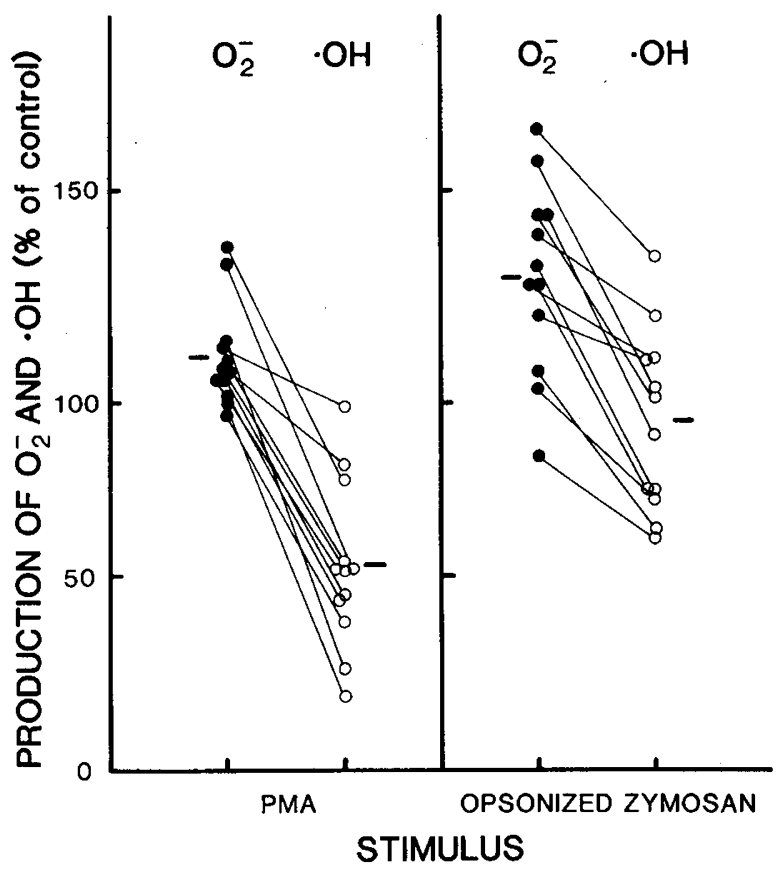

Fig. 1. Superoxide anion $\left(\mathrm{O}_{2}^{-}\right)$and hydroxyl radical ( $\left.\mathrm{OH}\right)$ production by neutrophils from cord blood after stimulation with PMA and opsonized zymosan. Oxygen metabolites by cord blood neutrophils are represented as percentage of simultaneously tested neutrophils from adults. Each point represents the mean of triplicate assays performed as described in "Materials and Methods." The bars represent the mean for the grpoup noted in that column. Absolute values for $\mathrm{O}_{2}^{-}$production were: newborn resting, $1.8 \pm 0.6 \mathrm{nmol} / 2.5 \times 0^{6}$ cells $/ 10 \mathrm{~min}$ (numbers represent \pm SEM, $n=12$ ), after stimulation with opsonized zymosan $35.9 \pm 4.8$, and $91.5 \pm 1.6$ with PMA; adult resting, $1.5 \pm 0.4,28.6 \pm 3.1$ with opsonized zymosan, and $88.2 \pm 2.8$ with PMA. Absolute values for $\mathrm{OH}$ generation were: newborn resting, $35.8 \pm 8.8 \mathrm{pmol} / 2.5 \times 10^{6}$ cells $/ 60 \mathrm{~min}$, opsonized zymosan $267.0 \pm 59.6$, and PMA 438.1 \pm 82.0 ; adult resting, $30.9 \pm 7.2$, opsonized zymosan $300.5 \pm 57.6$, and PMA $840.3 \pm 116.8$.

neutrophils released slightly, but not significantly, increased amounts of MPO and there was no significant difference in lysozyme release. Thus, the process of degranulation appeared to be equivalent in neutrophils from adults and newborns.

To explore the possibility that the abnormality in ${ }^{\circ} \mathrm{OH}$ production in newborn neutrophils was related to content of granuleassociated proteins, total content of MPO, lysozyme, and LF were quantitated in cord blood and adult cells, and the results are presented in Table 1 . The content of MPO, the primary constituent of azurophilic granules, was similar for both newborn and adult samples. In contrast, lysozyme, contained in both specific and azurophilic granules, was mildly but significantly decreased; and LF, the primary constituent of specific granules, was reduced in newborn neutrophils to a level less than half that of adult cells. These data are consistent with a decrease in specific granules or their contents in newborn neutrophils.

To determine whether the results represented a uniform decrease in LF or specific granules (or both) in all cells and not complete depletion in a subpopulation of cells, methanol-fixed peripheral blood smears from nine newborn and adult subjects were examined with an immunofluorescence technique for LF. With this technique, neutrophils demonstrated diffuse, punctate, cytoplasmic fluorescence. When the IgG fraction of rabbit antilactoferrin was omitted and smears were incubated only with fluorescein-conjugated goat antirabbit immunoglobulin, no fluorescence was noted in neutrophils. No fluorescence was seen in normal platelets, erythrocytes, monocytes, or lymphocytes. Although the fluorescence appeared decreased in newborn neutrophils compared to that in adult cells, the distribution was uniform 

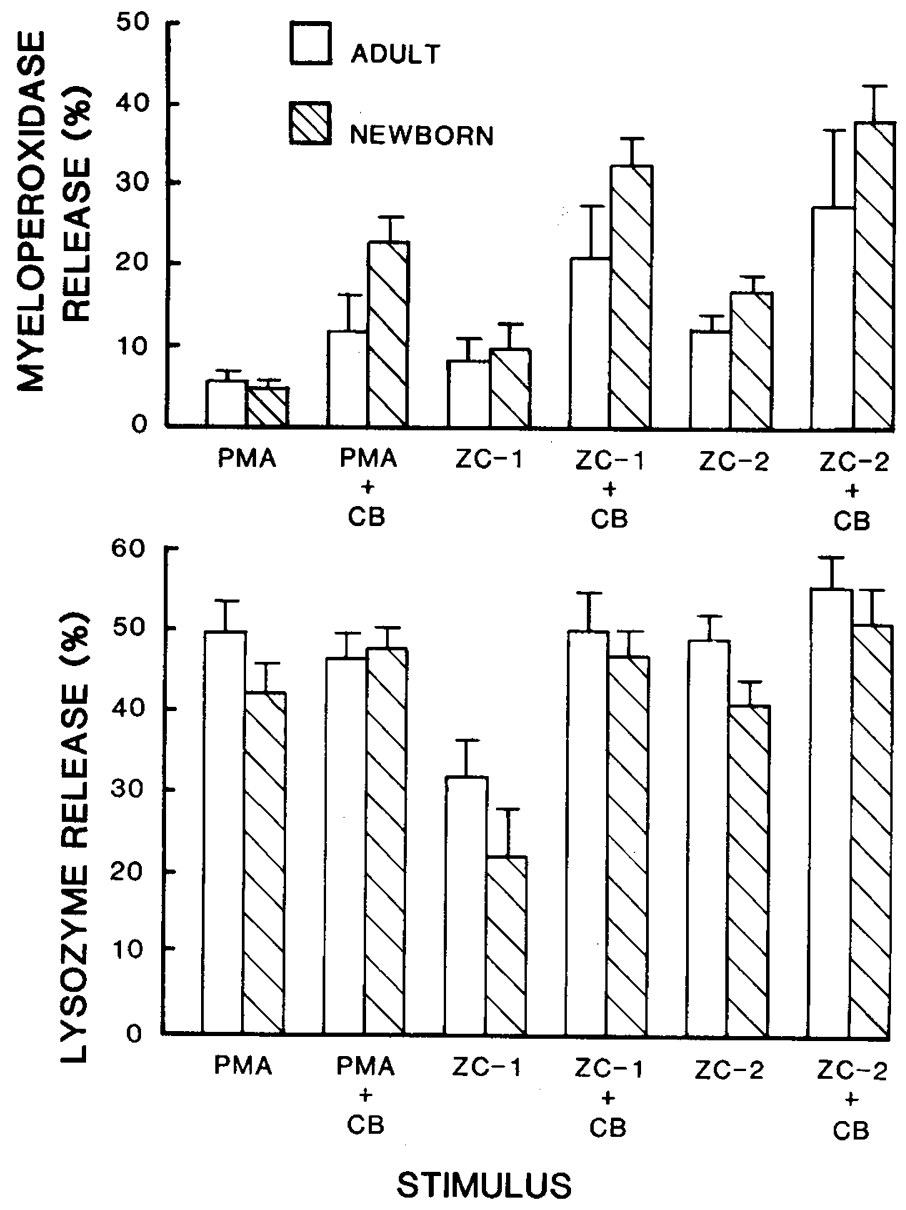

Fig. 2. Exocytosis of myeloperoxidase and lysozyme after stimulation with PMA and two concentrations of opsonized zymosan, $Z C-1=0.4$ $\mathrm{mg} / \mathrm{ml}$ and $A C-2=1 \mathrm{mg} / \mathrm{ml}$. The bars and brackets represent the mean and SEM of duplicate assays performed on neutrophils from nine cord blood samples ( hatched bars) and nine simultaneously tested adults (open bars) as outlined in "Materials and Methods."

Table 1. Total content of granule-associated proteins*

\begin{tabular}{lcc}
\hline \multicolumn{1}{c}{ Protein } & Adult & Newborn \\
\hline $\begin{array}{l}\text { Myeloperoxidase } \\
(A \text { units }) \dagger\end{array}$ & $204 \pm 24(9)$ & $201 \pm 21(9)$ \\
$\begin{array}{l}\text { Lysozyme } \\
(A \text { units }) \dagger\end{array}$ & $111 \pm 10(9)$ & $89 \pm 6 \ddagger(9)$ \\
Lactoferrin $(\mu \mathrm{g} / \mathrm{mg}$ total protein $)$ & $89.0 \pm 7.3(11)$ & $43.2 \pm 7.0 \S(11)$ \\
\hline
\end{tabular}

* Numbers represent mean \pm SEM with the numbers of subjects studied in parentheses.

$\dagger A$ units, $\triangle A / 4 \times 10^{6}$ cells $/ \mathrm{min} \times 10^{3}$.

$¥$ Significant difference between newborn and adult neutrophils, $p<$ 0.05 by paired $t$ test.

$\S$ Significant difference between newborn and adult neutrophils, $p<$ 0.005 by paired $t$ test.

from cell to cell, excluding the existence of different populations of cells with varying concentrations of LF.

In order to explore the relationship between $\mathrm{OH}$ production in response to PMA and total LF content, we measured these variables in neutrophils from seven cord blood samples and seven simultaneously obtained normal adults. Generation of $\mathrm{OH}$ was less for each cord blood sample than for the simultaneously tested adult sample (Fig. 3), and the differences were significant at $p<0.005$ (paired $t$ test). LF content was also less in the newborn compared to control cells $(p<0.005)$; and when the generation of. OH was plotted against LF content for cord

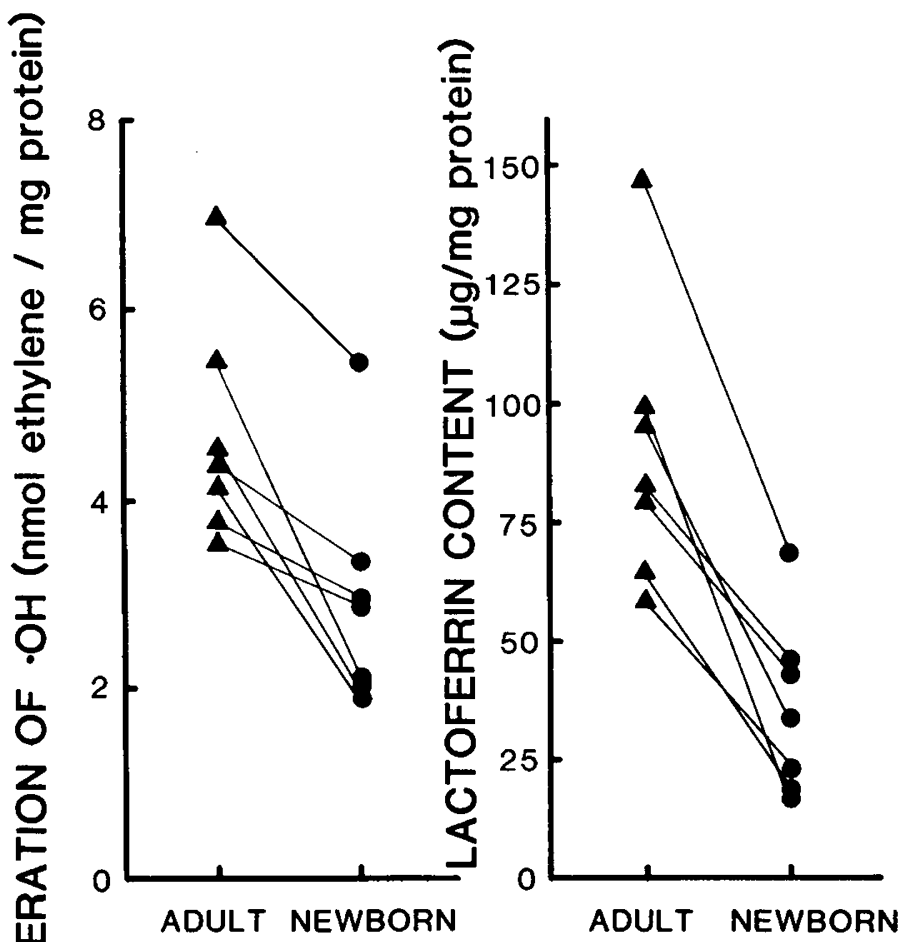

Fig. 3. Generation of ${ }^{\prime} \mathrm{OH}$ and lactoferrin content of neutrophils from seven cord blood-adult pairs. $\mathrm{OH}$ is represented as thiourea-inhibitable ethylene production. Both $\mathrm{OH}$ generation and lactoferrin are expressed per mg total protein. There was no difference between total protein content of adult or cord blood neutrophils: adult, $0.26 \pm 0.02 \mathrm{mg} / 2.5 \times$ $10^{6}$ cells (mean \pm SEM, $\left.n=7\right)$; newborn, $0.24 \pm 0.03(n=7)$.

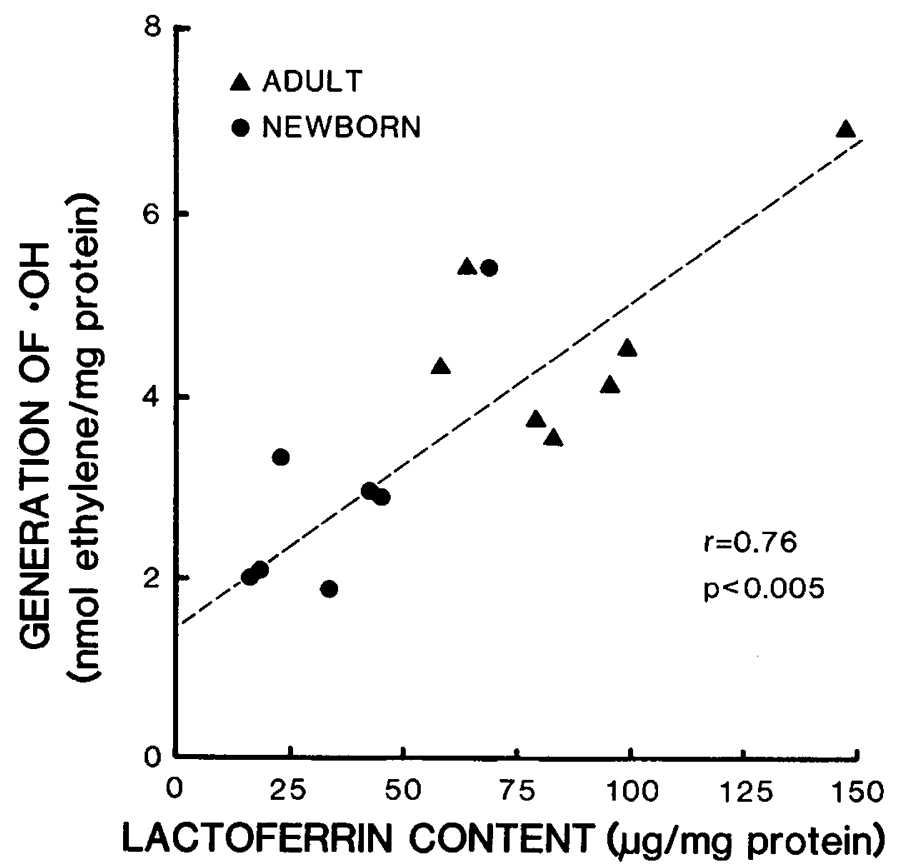

Fig. 4. Generation of $\mathrm{OH}$ plotted against total LF content adult ( $(\mathbf{\Delta})$ and cord blood $(\bullet)$ neutrophils.

blood and adult neutrophils (Fig. 4), there was a significant direct correlation between the two $(r=0.76, p<0.005$, linear regression analysis).

To evaluate further the cause of diminished LF and lysozyme 
Table 2. Evaluation of granule classes in cord blood and adult neutrophils by electron microscopy*

\begin{tabular}{lcc} 
Granule class & $\begin{array}{c}\text { Adult } \\
(\%)\end{array}$ & $\begin{array}{c}\text { Newborn } \\
(\%)\end{array}$ \\
\hline Azurophilic & $51 \pm 1$ & $50 \pm 2$ \\
Specific & $41 \pm 1 \dagger$ & $32 \pm 1$ \\
Undetermined & $9 \pm 2 \dagger$ & $18 \pm 2$ \\
\hline
\end{tabular}

* Results for each granule class are expressed as percentage of total granules as described in "Materials and Methods." The numbers represent mean \pm SEM of three adult and four cord blood samples. For each sample, data was obtained from 11 sections, each from a different neutrophil. In each section, 85 to 300 granules were classified into one of the three groups of granules. Results for each sample were determined from the average of 11 sections.

$\uparrow$ Significant difference between newborn and adult samples $(p<0.01$ by unpaired $t$ test).

content in newborn cells, electron microscopic studies were performed, and the results are summarized in Table 2 . There was a significant decrease in specific granules and this was associated with an increase in granules of the "undetermined" classification in newborn neutrophils compared to adult controls. These studies suggested that degranulation of specific granules had occurred in the cord blood neutrophils to a greater extent than was seen in cells from adult controls.

\section{DISCUSSION}

Neutrophils provide a major defense against bacterial infection. Diminished bactericidal $(11,35)$ and candidicidal (44) activity by neutrophils from neonates has been documented. The defect in killing of bacteria becomes more distinct when higher bacteria-to-cell ratios are used in the assays (43). Decreased in vitro microbicidal activity has also been demonstrated in stressed or infected infants $(2,33)$. The inability to kill ingested microbes efficiently may be an important factor in the increased risk of severe infection in the newborn.

The process of microbicidal activity by neutrophils is complex and probably requires both oxygen-dependent and oxygen-independent mechanisms. To date, studies of newborn neutrophils have centered around oxidative metabolism. Hexose monophosphate shunt activity of newborn neutrophils is increased both at rest and after stimulation $(2,26,32)$. However, the ratio of shunt activity in stimulated compared to resting cells is diminished compared to neutrophils from adults. Elevated oxygen consumption (2), increased reduction of nitroblue tetrazolium dye (2), and elevated $\mathrm{O}_{2}^{-}$generation after stimulation have been documented in newborn cells $(3,26,38)$. In contrast, deficient chemiluminescence in response to particulate and soluble stimuli by newborn neutrophils has been reported $(32,40)$. In addition, one report has suggested that activities of catalase and glutathione peroxidase are diminished in newborn neutrophils (15). The ability of the neutrophil to protect itself against the activity of toxic oxygen metabolites may be impaired in neonates, and this may explain the diminished HMPS activity and other abnormalities in oxidative metabolism exhibited by infected or stressed newborns $(2,33)$.

Initiation of oxidative antimicrobial systems occurs with activation of the respiratory burst, a complex sequence of metabolic changes occurring after ingestion. Oxygen enters the cells and is reduced to $\mathrm{O}_{2}^{-}$under the direction of an oxidase associated with the plasma membrane that uses NADPH as a source of electrons (15). In an acidic environment, $\mathrm{O}_{2}^{-}$dismutates to $\mathrm{H}_{2} \mathrm{O}_{2}$. Activation of the hexose monophosphate shunt also occurs. The importance of this oxidative burst in neutrophils is demonstrated by patients with chronic granulomatous disease whose neutrophils do not undergo this burst of metabolism after a bacterial challenge and whose neutrophils cannot kill bacteria and fungi normally (17).
The precise interrelationship between the various oxygen metabolites generated by phagocytes and microbial death has not been fully defined. By themselves, $\mathrm{O}_{2}^{-}$and $\mathrm{H}_{2} \mathrm{O}_{2}$ are weakly bactericidal. Studies using neutrophils or chemical systems suggests that the product of the interaction between these two metabolites, $\mathrm{OH}$, is a critically important oxygen metabolite in microbial killing $(16,30,31)$. Generation of $\mathrm{OH}$ efficiently in chemical and biological systems depends on the presence of iron $(28,29)$. Thus, iron-binding proteins located within the neutrophil have potential to contribute to microbicidal activity.

As the microorganism becomes entrapped in the phagosome, oxygen metabolites produced as a result of the respiratory burst are released in the microbe. Cytoplasmic granules from the two major classes fuse with and release their contents into the phagocytic vacuole (36). Recent studies in our laboratory have shown that both the NADPH-dependent respiratory burst enzyme(s) and components of cytoplasmic granules are necessary for efficient killing of bacteria (M. Sasada, D. R. Ambruso, L. A. Guthrie, and R. B. Johnson, Jr., submitted for publication). In addition, several studies have demonstrated that constituents of cytoplasmic granules, LF and MPO, promote bactericidal activity and/or enhance $\mathrm{OH}$ production $(4,18,19)$.

The current study was undertaken to explore oxygen metabolite generation and its relationship to the content and degranulation of cytoplasmic granules in neutrophils from cord blood. In a prelminary report, we demonstrated relatively less $\mathrm{OH}$ generation compared to $\mathrm{O}_{2}^{-}$production by cord neutrophils (3), which was confirmed by results of the larger study reported here. The decreased $\mathrm{OH}$ production by neutrophils from cord blood was not explained by abnormal release of cytoplasmic granule contents in that stimulated exocytosis of specific and azurophilic granules was no different to PMA or opsonized zymosan for neutrophils from cord blood and those from normal adults. Thus, abnormal delivery of granule contents into the phagosome is not likely to underlie defects in oxidative metabolism of the neutrophils from newborns.

The decreased content of LF in the face of normal levels of MPO and moderately decreased levels of lysozyme is consistent with a quantitative deficiency of specific granules or their contents, and the fluorescence studies showed this to be a uniform change in all cells, not complete depletion in a subpopulation of cells. The generation of $\mathrm{OH}$ in newborn and adult neutrophils appeared to be directly related to LF content. In light of previous studies showing that LF can efficiently present iron to $\mathrm{OH}-$ generating systems (4), our data are consistent with the hypothesis that decreased content of LF in neutrophils from cord blood results in decreased delivery of this protein into the phagosome and decreased $\mathrm{OH}$ production. This deficit may underlie the diminished microbicidal activity demonstrated by newborn neutrophils.

The same mechanism may be operative in patients with congenital absence of specific granules and of LF and recurrent bacterial infections. Five such patients have been reported $(10$, $20,27,34,37)$. All have demonstrated diminished bactericidal activity. Defective oxidative metabolism has been demonstrated in three, including decreased $\mathrm{OH}$ generation in two $(5,9,13)$.

Two possibilities exist for the decreased content of lysozyme and lactoferrin in neutrophils from newborns: a decrease in the number of specific granules or a diminished content of these proteins within the specific granules. Our data suggest that there is significant degranulation in cord blood neutrophils, which is associated with a decreased number of specific granules. These morphologic data, however, do not rule out a concomitant decrease in the contents of the specific granules that are present.

The cause for degranulation of cord blood neutrophils is not known but may be related to events of parturition. Recent studies have suggested a difference in oxidative metabolism between infants who undergo labor before delivery and those who do not (12). Increased $\mathrm{O}_{2}^{-}$generation along with degranulation, could represent activation of cord blood neutrophils. Borregaard and 
Tauber (8) have shown that stimulation of the respiratory burst is associated with movement of cytochrome $b$ and flavoprotein, found associated with specific granules, to the plasma membrane. Thus, stimulation of fetal neutrophils during labor could result in degranulation, activation of the respiratory burst, and increased $\mathrm{O}_{2}^{-}$generation. It is interesting that neutrophils from mothers pre- and postpartum have normal levels of myeloperoxidase and increased levels of lactoferrin (25). However, the defects reported here in cord blood neutrophils have important implications for neutrophil function during the perinatal period and may be related to the increased susceptibility to infection during this time.

Acknowledgments. We wish to acknowledge Beverly Polt for her help in the preparation of the manuscript and Shirley Dougherty for her technical help with several aspects of this project.

\section{REFERENCES}

1. Anderson DC, Hughes BJ, Smith WC 1981 Abnormal motility of neonatal polymorphonuclear leukocytes: relationship to impaired redistribution of surface adhesion sites by chemotactic factor or colchicine. J Clin Invest 68:863

2. Anderson DC. Pickering LK, Feigin RD 1974 Leukocyte function in normal and infected neonates. J Pediatr 85:420

3. Ambruso DR, Altenburger K, Johnston RB Jr 1979 Defective oxidative metabolism in newborn neutrophils: discrepancy between superoxide anion and hydroxyl radical generation. Pediatrics 64 (suppl.): 722

4. Ambruso DR, Johnston RB Jr 1981 Lactoferrin enhances hydroxyl radical production by human neutrophils and neutrophil particulate fractions, and an enzymatic generating system. J Clin Invest 67:352

5. Ambruso DR, Sasada M, Nishiyama H, Kubo A, Komiyama A, Allen RH 1984 Studies of neutrophil function in a patient with specific granule deficiency. J Clin Immunol 4:23

6. Babior BM 1978 Oxygen-dependent microbial killing by phagocytes. $\mathrm{N}$ Engl $\mathbf{J}$ Med 298:659

7. Bentwood BJ, Henson PM 1980 The sequential release of granule constituents from human neutrophils. J Immunol 124:855

8. Borregaard N, Tauber AI 1984 Subcellular localization of the human neutrophil NADPH oxidase: $b$-cytochrome and associated flavoprotein. J Biol Chem 259:47

9. Boxer LA, Coates TD, Haak RA, Walach JB, Hoffstein S, Baehner RL 1982 Lactoferrin deficiency associated with altered granulocyte function. N Engl J Med 307:404

10. Breton-Gorius J, Mason DY, Buriot D, Vilde JL, Griscelli C 1980 Lactoferrin deficiency as a consequence of a lack of specific granules in neutrophils from a patient with recurrent infections. Am J Pathol 99:413

11. Coen R, Grush O, Kauder C 1969 Studies of bactericidal activity and metabolism of the leukocyte in full-term neonates. J Pediatr 75:400

12. Frazier JP. Cleary TG, Pickering LK Kohl S Ross PJ 1982 Leukocyte function in healthy neonates following vaginal and cesarean section deliveries. $\mathrm{J}$ Pediatr 101:269

13. Gallin JI, Fletcher MP, Seligmann BE, Hoffstein S, Cehrs K, Mounessa N 1982 Human neutrophil-specific granule deficiency: a model to assess the role of neutrophil-specific granules in the evolution of the inflammatory response. Blood 59:1317

14. Goldstein I, Hoffstein S, Gallin J, Weissmann G 1973 Mechanisms of lysozymal enzyme release from human leukocytes: microtubule assembly and membrane fusion induced by a component of complement. Proc Natl Acad Sci USA 70:2916

15. Johnston RB Jr 1978 Oxygen metaoblism and the microbicidal activity of macrophages. Fed Proc 37:2759

16. Johnston RB Jr, Keele BB, Misra HP, Lehmeyer JE, Webb JS, Baehner RL
Rajagapalan KV 1975 The role of superoxide anion generation in phagocytic bactericidal activity. J Clin Invest 55:1357

17. Johnston RB Jr, Newman SL 1977 Chronic granulomatous disease. Pediatr Clin N Am 24:365

18. Klebanoff SJ 1980 Oxygen metabolism and the toxic properties of phagocytes Ann Intern Med 93:480

19. Klebanoff SJ, Rosen H 1978 Ethylene formation by polymorphonuclear leukocytes: role of myeloperoxidase. J Exp Med 148:490

20. Komiyama A. Marasawa H, Nakahata T, Miyagawa Y, Akabane T 1979 Abnormal neutrophil maturation in a neutrophil defect with morphologic abnormality and impaired function. J Pediatr 94:19

21. Laurell CB 1972 Electroimmunoassay. Scand J Lab Clin Invest 29:21

22. Lowry OH, Rosebrough NJ, Farr AL, Randall RJ 1951 Protein measurement with the Folin phenol reagent. J Biol Chem 193:265

23. Miller ME 1971 Chemotactic function in the human neonate: humoral and cellular aspects. Pediatr Res 5:487

24. Mills EL. Thompson T, Bjorksten B, Quie PG 1979 The chemiluminescence response and bactericidal activity of polymorphonuclear neutrophils from newborns and their mothers. Pediatrics 63:429

25. Oberg G, Lindmark G, Moberg L, Venge $P 1983$ The peroxidase activity and cellular content of granule proteins in PMN during pregnancy. Br J Haematol 55:701

26. Park BH, Holmes B, Good RA 1970 Metabolic activities in leukocytes of newborn infants. J Pediatr 76:237

27. Parmley RT, Ogawa M, Darby CP Jr, Spencer SS 1975 Congenital neutropenia: neutrophil proliferation with maturation. Blood 46:723

28. Repine JE, Fox RB, Berger EM 1981 Hydrogen peroxide kills Staphylococcus aureus by reacting with staphylococcal iron to form hydroxyl radical. J Biol Chem 256:7094

29. Rosen H, Klebanoff SJ 1981 Role of iron and ethylene diaminetetraacetic acid in the bactericidal activity of superoxide anion-generating system. Arch Biochem Biophys 208:512

30. Sagone AL, King GW, Metz EN 1976 A comparison of the metabolic response to phagocytosis in human granulocytes and monocytes. J Clin Invest 57:1352

31. Sasada M, Johnston RB Jr 1980 Macrophage microbicidal activity: correlation between phagocytosis-associated oxidative metabolism and the killing of Candida by macrophages. J Exp Med 152:85

32. Shigeoka AO, Charette RP, Wyman ML, Hill HR 1981 Defective oxidative metabolic responses of neutrophils from stressed neonates. J Pediatr 98:392

33. Shigeoka AO, Santos JI, Hill HR 1979 Functional analysis of neutrophil granulocytes from healthy, infected and stressed neonates. J Pediatr 95:454

34. Spitznagel JK. Cooper MR, McCall AE, Dechatelet LR, Welsh IRH 1972 Selective deficiency of granules associated with lysozyme and lactoferrin in human polymorphs with reduced microbicidal activity. J Clin Invest 51:93a (abstr)

35. Stoerner JW, Pickering LK, Adcock EW, Morriss FH Jr 1978 Polymorphonuclear leukocyte function in newborn infants. J Pediatr 93:862

36. Spitznagel JK, Leffell MS 1974 Intracellular and extracellular degranulation of human polymorphonuclear azurophil and specific granules induced by immune complexes. Infect Immun 10:1241

37. Strauss RG, Bove KE, Jones JF. Mauer AM, Fulginiti VA 1974 An anomaly of neutrophil morphology with impaired function. N Engl J Med 290:478

38. Strauss RG Snyder 1983 Activation and activity of the superoxide generating system of neutrophils from human infants. Pediatr 17:662

39. Strauss RG, Seifert MJ 1978 Oxidative metabolism in cord-blood polymorphonuclear leukocytes. Arch Dis Child 53:78

40. Strauss RG, Snyder EL. Wallace PD, Rosenberger TG 1980 Oxygen-detoxifying enzymes in neutrophils of infants and their mothers. J Lab Clin Med 95:897

41. Van Epps DE, Goodwin JS, Murphy S 1978 Age-dependent variations in polymorphonuclear leukocyte chemiluminescence. Infect Immun 22:57

42. Weeks B 1973 Crossed immunoelectrophoresis. Scand J Immunol 2 (Suppl 1):47

43. Wright WC Jr, Ank BJ Herbert J, Stiehm R 1975 Decreased bactericidal activity of leukocytes of stressed newborn infants. Pediatrics 56:579

44. Xanthau M, Valassi-Adam E. Kintzonidou E, Matsaniotis N 1975 Phagocytosis and killing ability of Candida alibcans by blood leukocytes of healthy term and preterm babies. Arch Dis Child 50:72 